\title{
MAKNA BERPIKIR SPASIAL MASYARAKAT MINANGKABAU DALAM LOGO PEMERINTAHAN DAERAH DI SUMATERA BARAT
}

\author{
Muhammad Aliman', Silvia Marni ${ }^{2}$, Budijanto', ${ }^{1}$ Sumarmi ${ }^{1}$, I Komang Astina ${ }^{1}$ \\ 1Pascasarjana Pendidikan Geografi, Universitas Negeri Malang \\ J1. Semarang 5 Malang, 65145, Indonesia \\ 2Pendidikan Bahasa dan Sastra Indonesia, STKIP PGRI Sumatera Barat \\ Jl. Gn. Pangilun, Padang, Sumatera Barat, 25173, Indonesia \\ e-mail: alviageo@gmail.com
}

Diterima: 1 Mei 2019; Direvisi: 19 Juni 2019; Disetujui: 14 Juli 2019

\begin{abstract}
Abstrak
Tujuan penelitian ini memberikan deskripsi tentang makna yang terkandung dari tanda dan simbol pada logo pemerintahan daerah di Propinsi Sumatera Barat. Metode deskriptif kualitatif digunakan untuk mengkaji tema pada artikel ini dengan pendekatan semiotik. Pendekatan semiotik yang digunakan adalah analisis denotasi dan konotasi. Logo pemerintahan daerah yang dijadikan subjek penelitian mewakili daerah kepulauan, daerah pesisir, daerah dataran rendah dan daerah dataran tinggi. Unsur spasial untuk menganalisis makna logo menggunakan unsur spasial menurut Sharpe dan Huynh. Hasil penelitian menjelaskan makna yang terkandung pada logo pemerintahan daerah berasal dari kearifan lokal masyarakat setempat yang mewakili berbagai elemen fisik maupun non fisik. Salah satu makna yang terkandung adalah elemen fisik berupa unsur spasial. Hal ini menjelaskan bahwa pemikiran masyarakat Minangkabau sejak dahulu berasal dari unsur-unsur spasial dalam kehidupannya. Makna pada logo pemerintahan daerah perlu diungkapkan secara terbuka agar masyarakat dan pegawai pemerintahan dapat mengetahui dan memahami serta memaknainya sebagai kekayaan kearifan lokal yang harus dijaga, diamalkan dan dilestarikan.
\end{abstract}

Kata kunci: Berpikir Spasial, Kearifan Lokal, Minangkabau, Semiotik

\begin{abstract}
The purpose of this research is to provide a description of the meaning contained in signs and symbols on the logo of regional government in West Sumatra Province. Qualitative descriptive method is used to examine the theme in this article with a semiotic approach. The semiotic approach used is the analysis of denotations and connotations. The logo of the regional government that was used as the research subject represented islands, coastal areas, lowland areas and highland areas. Spatial elements to analyse the meaning of logos using spatial elements according to Sharpe and Huynh. The results of the study explain the meaning contained in the logo of regional government derived from the local wisdom of the local community, which represents various physical and non-physical elements. One of the meanings contained is a physical element in the form of spatial elements. This explains that the thinking of the Minangkabau community has long been derived from spatial elements in his life. The meaning of the logo of regional government needs to be disclosed openly so that the public and government employees can know and understand and interpret it as a wealth of local wisdom that must be maintained, practised and preserved.
\end{abstract}


Key words: Spatial Thinking, Local Wisdom, Minangkabau, Semiotic

\section{PENDAHULUAN}

Indonesia merupakan kumpulan masyarakat yang terdiri dari berbagai latar belakang agama dan budaya. Dalam kelompok masyarakat tersebut, tumbuh dan berkembang pengetahuan, kebiasaan hidup yang dilakukan secara turun temurun (Alam \& Kusumasari, 2012). Pengetahuan dan kebiasaan tersebut menjadi sebuah kearifan lokal yang merupakan ciri khas dari kelompok masyarakat. Kearifan lokal ini merupakan bentuk penyesuaian hidup manusia terhadap kondisi alam dan lingkungannya (Meliono, 2016).

Berbagai macam bentuk dan wujud kearifan lokal telah tumbuh dan berkembang sejak lama di masyarakat Indonesia sebagai hasil interaksi manusia dengan lingkungannya (Aliman, 2018). Kearifan lokal tersebut dapat berupa tata aturan, kebiasaan hidup, ritual-ritual, kesenian dan sistem kehidupan lainnya. kearifan lokal tersebut telah menyatu dalam kehidupan masyarakat setempat. Kehidupan masyarakat yang diwarnai oleh kearifan lokal juga telah menjadi karakteristik dari masyarakat, sehingga orang diluar kelompok tersebut mampu memberikan tanda dan mengenal bahwa karakter tersebut berasal dari budaya atau kelompok masyarakat tertentu.

Saat ini, ciri khas yang terpancar dari karakter masyarakat setempat mulai memudar. Masuknya informasi dan teknologi ke Indonesia secara cepat, turut mempengaruhi perubahan budaya masyarakat lokal (Mubah, 2011). Berbagai pengaruh melalui berbagai media memberikan sumbangsih yang besar terhadap proses imitasi budaya dan personal seseorang di luar kelompok masyarakat lokal tersebut. Memudarnya karakter asli masyarakat lokal turut mempengaruhi terlaksananya kearifan lokal keseharian. Berbagai aturan dan sistem yang ada mulai mengalami pelemahan yang disebabkan oleh perubahan budaya tersebut.

Karakteristik masyarakat yang tercermin dari kuatnya keterlaksanaan kearifan lokal merupakan modal besar bangsa Indonesia dalam era persaingan antar bangsa (Aliman, 2018; Aliman \& Arif, 2017). Sebagai salah satu modal dan ciri khas bangsa Indonesia, kearifan lokal penting untuk tetap dilestarikan. Pentingnya kearifan lokal dilestarikan, dikarenakan memiliki berbagai manfaat, antara lain membentuk sikap dan perilaku masyarakat dalam menjaga lingkungan sekitarnya (Sufia, Sumarmi, \& Amirudin, 2016). Kearifan lokal juga memiliki nilai moral dan etika yang berisi aturan dalam menjaga sumber mata air (Sumarmi, 2015). Selain itu, kearifan lokal mampu melestarikan keutuhan hutan pada masyarakat Bali Aga dan Masyarakat Samin (Sumarmi, 2016).

Sebagai salah satu suku di Indonesia, Minangkabau merupakan suku bangsa yang ada di Provinsi Sumatera Barat. Suku ini memiliki adat istiadat yang memegang teguh akar budayanya tanpa berseberangan dengan agama yang dianut secara mayoritas masyarakat Minangkabau yaitu islam. Masyarakat Minangkabau memiliki falsafah hidup yaitu "Adat Basandi Syarak, Syarak Basandi Kitabullah". Falsafah ini mengandung arti bahwa aturan hidup masyarakat Minangkabau menyesuaikan dengan aturan agama islam. Pemangku adat yang berperan melestarikan kebiasaan lama mengakui bahwa adat yang diterapkan oleh masyarakat harus berlandaskan aturan-aturan agama islam (Yulika, 2017).

Tata hidup masyarakat Minangkabau diwujudkan dalam berbagai atribut fisik dan non fisik. Atribut fisik 
antara lain arsitektur rumah adat, tata kelola wilayah adat, pakaian adat, kerajinan tangan, alat musik, dan peralatan tradisional lainnya. Sedangkan atribut non fisik berupa tradisi lisan seperti ungkapan, pepatah petitih, mamangan, randai, tarian adat, kaba, simbol adat dan lainnya.

Budaya Minangkabau yang diwarisi secara turun-temurun oleh masyarakat terdahulu merupakan kekayaan yang bernilai tinggi. Budaya tersebut menjadi tuntunan bagi masyarakat dalam hidup kesehariannya. Budaya yang diterapkan dalam kehidupan keseharian berisikan tanda dan simbol. Tanda dan simbol yang memiliki makna ini merupakan perwujudan dari pertanda, penanda, dan tanda komunikasi antara masyarakat (Berger, 2015).

Tanda dan simbol merupakan alat dalam interaksi diantara masyarakat. Seperti halnya pepatah petitih yang mengandung ungkapan untuk merepresentasikan sesuatu fenomena dengan menganalogikannya dengan alam atau fenomena lainnya. Budaya Minangkabau sangat erat dengan alam, dibuktikan dengan falsafah "Alam Terkembang Jadi Guru"(Navis, 1984). Falsafah ini bagi masyarakat Minangkabau dijadikan rumusan sebagai ilmu dalam mengenal kehidupan. Kejadian kehidupan dapat dipelajari dengan mempelajari fenomena alam.

Fenomena alam yang dialami masyarakat Minangkabau dijadikan kearifan lokal sebagai salah satu bentuk adaptasi hidup bersama alam. Kearifan lokal masyarakat Minangkabau mengandung makna keilmuan unsur-unsur alam, non alam dan interaksi keduanya (Ws, 2015). Kearifan lokal tersebut kemudian diwujudkan dalam bentuk tanda dan simbol. Tanda dan simbol dalam mengenal alam juga bagian dari kearifan dalam mengenal ruang dan waktu (spasial).
Kondisi spasial di Minangkabau menyebabkan Minangkabau memiliki karakteristik dibandingkan dengan spasial budaya daerah lain. Kondisi spasial Minangkabau dapat dilihat dari berbagai komponen kehidupan masyarakatnya. Komponen tersebut terwujud karena bentuk dan pola pikir masyarakatnya. Bentuk dan pola berpikir spasial masyarakat Minangkabau dapat diketahui dari simbol dan atribut yang dikenakan. Salah satu simbol yang merupakan wujud berpikir spasial masyarakat Minangkabau tercermin dari logo pemerintahan daerah yang ada di masing-masing daerah Sumatera Barat.

Bentuk dan pola berpikir spasial tersebut dikaji berdasarkan indikator berpikir spasial menurut ahli spasial. Penelitian ini menggunakan indikator berpikir spasial menurut Huynh \& Sharpe (2013). Adapun indikator berpikir spasial yang digunakan antara lain representasi, analisis, skala (perbandingan), interaksi spasial, komprehensif, dan aplikasi (Aliman et al., 2019; Huynh \& Sharpe, 2013). Indikator berpikir spasial digunakan untuk mengkaji kemampuan berpikir spasial masyarakat Minangkabau yang disimbolkan dengan logo pemerintahan daerah.

Banyak penelitian yang telah mengkaji budaya Minangkabau dari berbagai pendekatan antara lain: tradisi lisan (Ws, 2015), tari minang (Yuningsih, 2015), musik dalam randai (Rustiyanti, 2014), Pantun (Gani, 2012), arsitektur rumah adat (Suharjanto, 2011), dan simbol religius rumah gadang (Gusman, 2011). Namun penelitian yang mengkaji pemaknaan simbol yang ada pada logo pemerintahan daerah di Sumatera Barat belum banyak diteliti. Logo pemerintahan daerah yang dimiliki setiap daerah memiliki arti dan makna tertentu karena mencerminkan kondisi masyarakat dan daerah tersebut. Tidak semua masyarakat 
mengetetahui arti dan makna dari simbolsimbol tersebut. Diperlukan upaya untuk mengkaji dan mengungkapkan arti serta makna simbol-simbol tersebut khususnya dalam melihat kemampuan berpikir spasial masyarakat Minangkabau.

\section{METODE PENELITIAN}

Penelitian dalam artikel ini menggunakan metode deskriptif kualitatif. Penelitian ini berusaha untuk mengungkapkan makna dibalik logo pemerintahan daerah di Propinsi Sumatera Barat. Pendekatan yang dilakukan untuk melakukan kajian mendalam pada makna dibalik logo pemerintah daerah adalah menggunakan pendekatan semiotik. Pendekatan semiotik banyak dilakukan karena merupakan pendekatan yang tepat untuk mengkaji pemaknaan dibalik simbol dan tanda, seperti penelitian analisis semiotik dalam film (Simatupang, 2017). Logo yang menjadi pilihan untuk dikaji dalam artikel ini merupakan logo pemerintahan daerah yang mewakili kota dan kabupaten di Propinsi Sumatera Barat berdasarkan kondisi geografis yang berbeda. Propinsi Sumatera Barat memiliki 12 wilayah kabupaten dan 7 wilayah kota, dari kabupaten dan kota tersebut dipilih 4 wilayah yang mewakili empat perbedaan daerah secara geografis. Penjelasan lebih rinci dapat dilihat pada tabel berikut.

Tabel 1: Logo Pemerintahan Daerah

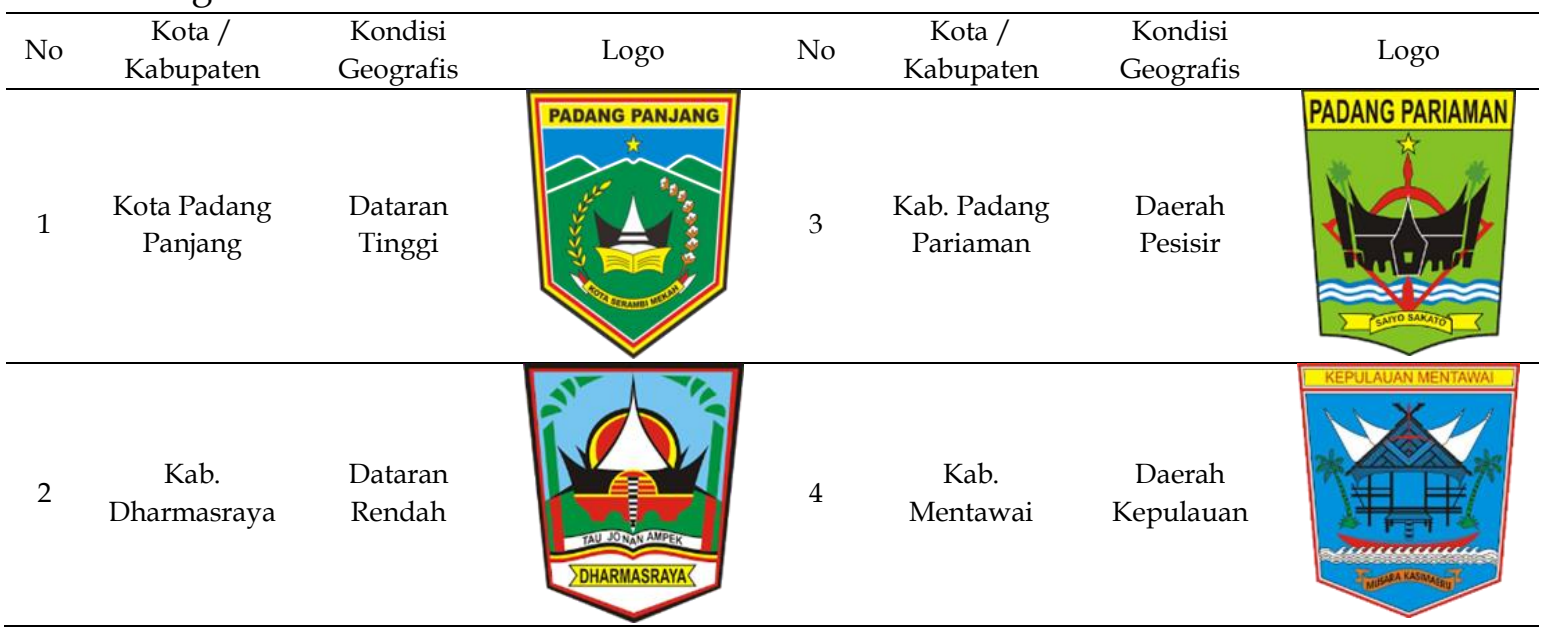

Sumber: Analisis peneliti, 2018

Dari tabel 1, simbol-simbol yang terdapat pada masing-masing logo pemerintahan daerah diklasifikasikan berdasarkan unsur fisik dan non fisik. Unsur fisik merupakan unsur yang berasal dari unsur alam dan unsur non fisik merupakan unsur buatan manusia atau bukan alam. Penelitian ini menggunakan unsur fisik karena sangat berdekatan dengan unsur-unsur spasial. Unsur-unsur spasial yang dimaksud antara lain 1) interaksi spasial, 2) skala, 3) representasi, 4) aplikasi, 5) komprehensif, dan 6) analisis (Huynh \& Sharpe, 2013). Unsur spasial berkaitan dengan komponen dalam ruang, sedangkan ruang yang dimaksud adalah wilayah. Dari simbol yang mengandung unsur spasial kemudian dimaknai secara konotasi dan denotasi. Pendekatan yang digunakan untuk mengungkapkan makna dibalik logo tersebut menggunakan pendekatan semiologi dengan analisis denotasi dan konotasi (Barthes, 1972). Makna denotasi diinterpretasi sesuai dengan makna yang sesungguhnya, sedangkan makna konotasi diinterpretasi berdasarkan makna dibalik makna yang terlihat secara eksplisit. Makna konotasi 
bahkan sering mengalami pergeseran makna, namun masih relevan dengan simbol dan tanda pada makna aslinya. Makna denotasi dan konotasi yang diungkapkan bertujuan untuk menggambarkan nalar berpikirnya.

\section{HASIL DAN PEMBAHASAN}

Dalam logo pemerintahan daerah tersebut mengandung berbagai simbol dan tanda. Kajian dalam pendekatan semiotik merupakan kebiasaan dalam ilmu komunikasi. Kebiasaan dalam teori ini mengajarkan cara untuk mengetahui tanda- tanda yang merupakan representasi dari ide, gagasan, fenomena, kondisi dan situasi diluar tanda-tanda itu sendiri (Littlejhon \& Foss, 2009) Pendekatan semiotik membantu mengetahui makna yang ada dibalik logo pemerintahan daerah. Pendekatan semiotik mampu menafsirkan pesan yang tersembunyi dari pembuat logo tersebut. Pemaknaan dalam logo tersebut tergambar dalam proses pemaknaan secara denotasi dan konotasi seperti tabel 2.

Tabel 2: Proses Pemaknaan Simbol Pada Logo Pemerintahan Daerah

\begin{tabular}{|c|c|c|c|c|}
\hline $\begin{array}{c}\text { Kota/ } \\
\text { Kabupaten }\end{array}$ & Simbol & Unsur Spasial & Denotasi & Konotasi \\
\hline \multirow{3}{*}{$\begin{array}{l}\text { Kota Padang } \\
\text { Panjang }\end{array}$} & $\begin{array}{l}\text { Tiga buah } \\
\text { gunung }\end{array}$ & $\begin{array}{l}\text { - Representasi } \\
\text { - Komprehensif } \\
\text { - Aplikasi }\end{array}$ & $\begin{array}{l}\text { Dikelilingi tiga buah gunung } \\
\text { yaitu Gunung Marapi, } \\
\text { Gunung Singgalang dan } \\
\text { Gunung Tandikek }\end{array}$ & $\begin{array}{l}\text { Gunung yang hijau } \\
\text { melambangkan kesejukan dan } \\
\text { kedamaian yang terpancar dari } \\
\text { masyarakat yang menjiwai } \\
\text { falsafah Minangkabau yaitu adat } \\
\text { bersandi syarak, syarak bersandi } \\
\text { kitabullah. }\end{array}$ \\
\hline & Garis putih & $\begin{array}{l}\text { - Interaksi } \\
\text { Spasial } \\
\text { - Aplikasi }\end{array}$ & $\begin{array}{l}\text { Kota Padang Panjang selalu } \\
\text { diselimuti awan, memiliki } \\
\text { suhu yang sejuk dengan } \\
\text { curah hujan tinggi }\end{array}$ & $\begin{array}{l}\text { Masyarakat memiliki hati yang } \\
\text { suci dan bersih dalam hidup } \\
\text { beragama sehingga kota ini diberi } \\
\text { julukan sebagai kota serambi } \\
\text { mekah. }\end{array}$ \\
\hline & $\begin{array}{l}\text { Setangkai } \\
\text { padi dan } \\
\text { kapas }\end{array}$ & $\begin{array}{l}\text { - Representasi } \\
\text { - Analisis } \\
\text { - Aplikasi }\end{array}$ & $\begin{array}{l}\text { Peringatan hari kemerdekaan } \\
\text { Indonesia }\end{array}$ & $\begin{array}{l}\text { Masyarakat mengakui wilayahnya } \\
\text { di bawah kekuasaan Negara } \\
\text { Kesatuan Republik Indonesia. }\end{array}$ \\
\hline \multirow[t]{2}{*}{$\begin{array}{l}\text { Kab. Padang } \\
\text { Pariaman }\end{array}$} & Pohon Kelapa & $\begin{array}{l}\text { - Aplikasi } \\
\text { - Interaksi } \\
\text { spasial }\end{array}$ & $\begin{array}{l}\text { Tanaman utama di daerah } \\
\text { Padang Pariaman yang juga } \\
\text { dijadikan sebagai salah satu } \\
\text { mata pencaharian penduduk }\end{array}$ & $\begin{array}{l}\text { - Jumlah pelepah daun yang } \\
\text { berjumlah } 17 \text { buah, memiliki } \\
\text { makna bahwa Padang Pariaman } \\
\text { terdiri dari } 17 \text { kecamatan. } \\
\text { - Pohon kelapa memiliki banyak } \\
\text { manfaat, begitu juga dengan } \\
\text { masyarakat Padang Pariaman } \\
\text { yang seharusnya juga dapat } \\
\text { memberikan manfaat sebanyak- } \\
\text { banyaknya. }\end{array}$ \\
\hline & Lautan & $\begin{array}{l}\text { - Aplikasi } \\
\text { - Interaksi } \\
\text { spasial } \\
\text { - }\end{array}$ & $\begin{array}{l}\text { Padang Pariaman memiliki } \\
\text { laut yang luas dan memiliki } \\
\text { garis pantai yang panjang }\end{array}$ & $\begin{array}{l}\text { Laut sebagai mata pencaharian } \\
\text { bagi penduduk yang berada } \\
\text { disekitar pesisir. }\end{array}$ \\
\hline \multirow{3}{*}{$\begin{array}{l}\text { Kab. } \\
\text { Kepulauan } \\
\text { Mentawai }\end{array}$} & $\begin{array}{l}\text { Dua Batang } \\
\text { Kelapa }\end{array}$ & $\begin{array}{l}\text { - Aplikasi } \\
\text { - Interaksi } \\
\text { spasial }\end{array}$ & $\begin{array}{l}\text { Daerah kepulauan } \\
\text { ditumbuhi } \begin{array}{r}\text { yang } \\
\text { kelapa. }\end{array}\end{array}$ & $\begin{array}{l}\text { - Mencerminkan bentuk keadilan } \\
\text { dalam kehidupan masyarakat } \\
\text { - Sebagian penduduk } \\
\text { memanfaatkan kelapa sebagai } \\
\text { mata pencaharian }\end{array}$ \\
\hline & $\begin{array}{l}\text { - } 12 \text { pelepah } \\
\text { daun kelapa } \\
\text { - } 10 \text { buah } \\
\text { kelapa } \\
\text { - } 99 \text { buah lidi }\end{array}$ & $\begin{array}{l}\text { - Skala } \\
\text { - Komprehensif }\end{array}$ & $\begin{array}{l}\text { Kab. Mentawai lahir pada } \\
\text { tanggal 12, bulan Oktober } \\
\text { dan tahun } 1999\end{array}$ & $\begin{array}{l}\text { Kab. Mentawai terbentuk saat era } \\
\text { reformasi dimulai. Hal ini } \\
\text { mengandung makna bahwa } \\
\text { masyarakat Mentawai memiliki } \\
\text { keinginan untuk memperbaiki diri } \\
\text { dan mencapai kemajuan. }\end{array}$ \\
\hline & Ombak & $\begin{array}{l}\text { - Aplikasi } \\
\text { - Interaksi } \\
\text { spasial }\end{array}$ & $\begin{array}{l}\text { - Kepulauan Mentawai } \\
\text { dikelilingi oleh lautan luas } \\
\text { dan berhadapan langsung } \\
\text { dengan Samudera Hindia. } \\
\text { - Daerah ini merupakan }\end{array}$ & $\begin{array}{l}\text { Kab. Mentawai memiliki potensi } \\
\text { wisata bahari yang besar, salah } \\
\text { satuny memiliki ombak yang } \\
\text { tinggi, terumbu karang, kawasan } \\
\text { mangrove dll. }\end{array}$ \\
\hline
\end{tabular}




\begin{tabular}{|c|c|c|c|c|}
\hline $\begin{array}{c}\text { Kota/ } \\
\text { Kabupaten }\end{array}$ & Simbol & Unsur Spasial & Denotasi & Konotasi \\
\hline & & & $\begin{array}{l}\text { daerah rawan bencana } \\
\text { gempa dan tsunami. }\end{array}$ & \\
\hline & Pohon & $\begin{array}{l}\text { - Aplikasi } \\
\text { - Interaksi } \\
\\
\text { spasial }\end{array}$ & $\begin{array}{l}\text { Kab. Dharmasraya memiliki } \\
\text { potensi hutan dan kebun } \\
\text { seperti hutan larangan, } \\
\text { kelapa sawit dan karet. }\end{array}$ & $\begin{array}{l}\text { Makna yang terkandung yaitu } \\
\text { pohon memiliki berbagai manfaat } \\
\text { antara lain fungsi hidrologis, } \\
\text { orologis, klimatologis dsb. } \\
\text { Dimanapun pohon berada selalu } \\
\text { memberikan manfaat dan } \\
\text { perlindungan. Sebagaimana } \\
\text { masyarakat Dharmasraya, } \\
\text { dimanapun ia berada selalu } \\
\text { memberikan manfaat bagi orang } \\
\text { lain. }\end{array}$ \\
\hline & $\begin{array}{l}\text { Hamparan } \\
\text { hijau }\end{array}$ & - Representasi & $\begin{array}{l}\text { Daerah yang subur dan } \\
\text { berpotensi untuk } \\
\text { dikembangkan pertanian, } \\
\text { peternakan dan kehutanan. } \\
\text { Potensi tersebut dapat } \\
\text { dimanfaatkan } \\
\text { kesejahteraan masyarakat. }\end{array}$ & $\begin{array}{l}\text { Hamparan hijau merupakan } \\
\text { bentuk terbuka dari bentang alam. } \\
\text { Hal ini dapat dimaknai bahwa } \\
\text { masyarakat Dharmasraya } \\
\text { merupakan masyarakat yang } \\
\text { terbuka dengan berbagai hal, } \\
\text { namun tetap memiliki aturan yang } \\
\text { sesuai dengan falsafah } \\
\text { Minangkabau. }\end{array}$ \\
\hline & $\begin{array}{l}\text { Gelombang } \\
\text { Air }\end{array}$ & $\begin{array}{l}\text { - Aplikasi } \\
\text { - Interaksi } \\
\text { spasial }\end{array}$ & $\begin{array}{l}\text { Melambangkan } \quad r \text { saluran } \\
\text { irigasi yang menjadi } \\
\text { infrastruktur penting bagi } \\
\text { lahan sawah di Kab. } \\
\text { Dharmasraya }\end{array}$ & $\begin{array}{l}\text { Sistem irigasi dimaknai sebagai } \\
\text { semangat untuk saling berbagi. } \\
\text { Sesuai dengan pepatah } \\
\text { Minangkabau: Barek Samo Dipikua, } \\
\text { Ringan Samo Dijinjiang (Semua } \\
\text { pekerjaan, baik yang berat } \\
\text { ataupun ringan dikerjakan } \\
\text { bersama-sama). }\end{array}$ \\
\hline $\begin{array}{c}\text { Kab. } \\
\text { Dharmasraya }\end{array}$ & $\begin{array}{l}\text { Motto: Tau Jo } \\
\text { Nan Ampek } \\
\text { (Empat hal } \\
\text { yang harus } \\
\text { diketahui) }\end{array}$ & $\begin{array}{l}\text { - Analisis } \\
\text { - Komprehensif } \\
\text { - Representasi }\end{array}$ & $\begin{array}{l}\text { - Nan Ampek di Adat (Empat } \\
\text { hal yang ada di adat): Asa } \\
\text { diri nan ampek (Asal diri } \\
\text { manusia dari empat hal) } \\
\text { yang terdiri dari Air, Api, } \\
\text { Angin dan Tanah. } \\
\text { - Nan Ampek (Empat hal) di } \\
\text { IPTEK: Mato angin nan } \\
\text { ampek (Empat arah mata } \\
\text { angin) yaitu utara, selatan, } \\
\text { timur dan barat. }\end{array}$ & $\begin{array}{l}\text { - Maknanya yaitu manusia tidak } \\
\text { boleh bersikap sombong karena } \\
\text { harus tahu asal usulnya dari } \\
\text { mana. } \\
\text { - Dapat dimaknai bahwa terdapat } \\
\text { berbagai tujuan hidup, namun } \\
\text { manusia diharapkan tetap } \\
\text { memiliki pedoman yang sesuai } \\
\text { dengan aturan agama dan adat. }\end{array}$ \\
\hline
\end{tabular}

Sumber: Analisis Penulis, 2018

Proses pemaknaan simbol yang terdapat pada empat logo pemerintahan daerah dianalisis secara denotasi dan konotasi. Pemilihan simbol diklasifikasikan berdasarkan unsur fisik/alam yang terdapat pada logo. Simbol tersebut kemudian dikelompokkan berdasarkan indikator berpikir spasial. Berikut ini pembahasan mendalam makna berpikir spasial dari simbol-simbol tersebut.

\section{Berpikir spasial dalam logo Kota Padang Panjang}

Kota Padang Panjang merupakan salah satu kota di Sumatera Barat yang berada di kawasan perbukitan. Memiliki suhu rata-rata $22,7^{\circ} \mathrm{C}$, berada di ketinggian
782 mdpl dengan curah hujan 2281 $\mathrm{mm} /$ tahun (Climate-Data, 2018a). Kota ini dikelilingi oleh tiga gunung api yaitu Gunung Singgalang, Gunung Marapi, Gunung Tandikek. Kondisi fisik Kota Padang Panjang juga tercermin dari logo pemerintah daerah seperti terlihat pada tabel 1.

Simbol yang terdapat pada logo pemerintah Kota Padang Panjang terdiri dari 11 simbol bentuk dan 7 simbol warna. Dari 11 simbol bentuk, unsur fisik yang terdapat pada logo ada tiga simbol yaitu simbol tiga buah gunung, simbol garis putih dan simbol setangkai padi dan kapas. Simbol tiga buah gunung merupakan representasi dari daerah Kota Padang 
Panjang yang berada di daerah yang sejuk. Selain itu, simbol gunung juga dapat dimaknai secara komprehensif bahwa keberadaan gunung merupakan satu kesatuan terhadap pemanfaatan potensi disekitarnya. Kemampuan berpikir komprehensif terhadap keberadaan gunung berdampak kepada sudut pandang potensi positif dan negatif. Potensi positif dari adanya gunung antara lain sebagai sumber air, hutan, ekowisata (Sumarmi, 2015) sedangkan potensi negatif seperti perubahan hutan menjadi tegalan dan permukiman dapat mengakibatkan tanah longsor (Wirda, 2016). Masyarakat yang mampu berpikir komprehensif dapat melihat hubungan dan dampak antara eksistensi hutan dengan perubahan lahan hutan.

Simbol garis putih mencerminkan bahwa Kota Padang Panjang memiliki curah hujan yang tinggi. Makna simbol ini merupakan bentuk interaksi antara kondisi alam dengan pemanfaatannya bagi masyarakat. Begitu juga dengan simbol setangkai padi dan kapas yang memiliki makna bahwa Kota Padang Panjang berada dibawah naungan negara kesatuan republik Indonesia (NKRI). Makna lain dari simbol padi dan kapas adalah daerah Padang Panjang merupakan daerah dengan potensi pertanian dan perkebunan. Pemanfaatan potensi ini diharapkan mampu meningkatkan kesejahteraan dan kemakmuran masyarakatnya.

\section{Berpikir Spasial dalam Logo Kabupaten Padang Pariaman}

Kabupaten Padang Pariaman sebagai salah satu daerah di pesisir barat Sumatera Barat memiliki suhu rata-rata $25,3^{\circ} \mathrm{C}$ dan curah hujan rata-rata 2642 $\mathrm{mm} /$ tahun dengan ketinggian $284 \mathrm{mdpl}$ (Climate-Data, 2018b). Padang Pariaman memiliki motto Saiyo Sakato yang dapat dimaknai sebagai kerukunan masyarakat yang saling bersama-sama, tolong menolong dalam mencapai tujuan bersama.

Logo pemerintah daerah Padang Pariaman terdiri dari lima simbol bentuk dan enam simbol warna. Dari beberapa simbol tersebut, hanya ada dua unsur fisik yang berkaitan dengan komponen spasial yaitu simbol pohon kelapa dan simbol lautan. Simbol pohon kelapa bagi masyarakat Padang Pariaman merupakan simbol memberikan manfaat. Hal ini sesuai dengan indikator berpikir spasial yaitu aplikasi. Kemampuan berpikir aplikasi merupakan kemampuan dalam menerapkan aturan-aturan hidup sehingga dapat memberikan manfaat secara maksimal. Selain aplikasi, simbol pohon kelapa mengandung makna berpikir dalam melihat hubungan antara komponen spasial/ruang. Simbol ini dapat diartikan secara konotasi sebagai kemampuan dalam melihat kesempatan dan potensi yang ada. Kemampuan interaksi spasial ini dibutuhkan dalam menghadapi persaingan antar bangsa.

Simbol lautan pada logo mengandung makna bahwa Padang Pariaman berada dekat dengan pantai dan memiliki laut yang didalamnya juga terdapat potensi untuk dimanfaatkan. Potensi ini dapat dimanfaatkan bagi masyarakat secara maksimal apabila masyarakat telah mempunyai kemampuan berpikir spasial. Kemampuan berpikir spasial yang dimaksud adalah kemampuan untuk melihat persamaan dan perbedaan antara komponen ruang yang ada disekitarnya. Secara nyata, masyarakat mampu memanfaatkan persamaan dan perbedaan yang berkaitan dengan laut, pantai dan pesisir antara lain atraksi wisata laut dan pantai. Pemanfaatan potensi alam berbasis Community Based Tourism (CBT) berdampak pada meningkatnya taraf kehidupan masyarakat lokal dibidang sosial, budaya dan ekonomi (Sugiharto, Delita, \& Sidauruk, 2018).

\section{Berpikir Spasial dalam Logo Kabupaten Mentawai}

Seperti halnya Padang Pariaman, Kabupaten Kepulauan Mentawai justru dikelilingi oleh lautan luas dan berhadapan langsung dengan Samudera Hindia. Kondisi ini mengakibatkan masyarakat Mentawai lebih mampu beradaptasi pada 
keadaan alam. Berbagai penelitian telah membuktikan bahwa kepulauan Mentawai merupakan daerah yang rawan dengan bencana gempa dan tsunami. Seperti kejadian gempa tanggal 25 Oktober 2010 dengan kekuatan 7,7 SR yang mengakibatkan tsunami dan menelan korban jiwa sebanyak 461 jiwa, namun kejadian ini cukup menarik karena dianggap menelan korban jiwa yang tidak sebanding dengan jumlah total penduduk di Kepulauan Mentawai (Syamsidik, Istiyanto, Tanto, \& Rachman, 2011). Keunikan ini, diduga dikarenakan karena adanya kemampuan adaptasi masyarakat yang tumbuh sejak lama dan berkembang hingga saat ini.

Kemampuan masyarakat Mentawai dalam beradaptasi dengan kondisi daerah yang rawan bencana merupakan kemampuan olah pikir masyarakat dalam mengenal dan memahami alam. Kemampuan dalam mengenal alam dan lingkungan akan menumbuhkan kecintaan terhadap daerahnya (Aliman, Mutia, \& Yustesia, 2018). Pemikiran seperti inilah yang dianggap kemampuan berpikir spasial, kemampuan mengetahui dan memprediksi kejadian alam tertentu dari mengenal tanda-tanda alam yang ada. Berdasarkan simbol-simbol yang ada pada logo pemerintah Kabupaten Mentawai, terdapat tiga unsur fisik yaitu simbol dua batang kelapa, simbol 12 pelepah daun kelapa, 10 buah kelapa dan 99 buah lidi, serta simbol ombak.

Simbol dua batang kelapa mengandung makna kemampuan berpikir aplikasi dan interaksi spasial karena masyarakat dapat memanfaatkan sumber daya alam yang ada seperti pohon kelapa yang tumbuh subur di pulau ini. Sedangkan simbol pelepah dauh kelapa, buah dan lidi mengandung makna bahwa masyarakat memiliki kemampuan komprehensif dan mampu membandingkan (skala) kondisi alam dengan keinginan untuk mencapai kesejahteraan dan kemakmuran. Masyarakat dibelajarkan untuk mengetahui potensi alam yang tersedia dan memanfaatkan potensi tersebut.

Simbol ombak, dapat dimaknai sebagai kemampuan berpikir aplikasi dan interaksi spasial. Kemampuan berpikir ini terbukti dengan kemampuan evakuasi diri $50 \%$ penduduk ketika terjadi tsunami ke daerah perbukitan (Syamsidik et al., 2011). Masyarakat memiliki kemampuan untuk menghubungkan komponen ruang seperti daerah yang dekat dengan pantai dan rendah dengan daerah yang tinggi dan jauh dari pantai dalam proses mengevakuasi diri menghindari tsunami. Seperti bertambahnya permukiman di Kecamatan Koto Tangah bagian timur yang disebabkan karena migrasi penduduk dari bagian barat (Pesisir pantai) pasca gempa tahun 2009 (Delita, 2016). Hal ini merupakan kemampuan berpikir aplikasi yang terlihat dari pemanfaatan daerah yang lebih tinggi untuk kawasan permukiman penduduk. Hal ini berdampak positif dalam mengurangi korban tsunami dikarenakan penataan ruang permukiman yang sesuai dengan arahan mitigasi bencana (Syamsidik et al., 2011).

\section{Berpikir Spasial dalam Logo Kabupaten Dharmasraya}

Kabupaten ini merupakan salah satu kabupaten termuda di Sumatera Barat. Kabupaten ini merupakan pemekaran wilayah dari Kabupaten Sijunjung. Daerah ini memiliki suhu rata-rata $27^{\circ} \mathrm{C}$, rata-rata ketinggian antara 100-1500 mdpl dengan curah hujan 3488 mm/tahun (BMKG, 2018). Kondisi alam seperti ini berdampak pada aktivitas masyarakat yang memanfaatkan air melimpah untuk lahan persawahan, pertanian dan perkebunan. Dari logo pemerintah Kabupaten Dharmasraya terdapat empat simbol unsur fisik yaitu simbol pohon, simbol hamparan hijau, simbol gelombang air dan simbol motto Tau Jo Nan Ampek.

Aktivitas masyarakat tersebut sesuai dengan simbol yang ada pada logo pemerintah daerah yaitu simbol pohon dan gelombang air yang mengandung makna aplikasi dan interaksi spasial. Makna dari 
simbol ini dapat diartikan bahwa masyarakat Kabupaten Dharmasraya dapat memanfaatkan potensi sumber air dengan luas lahan yang ada melalui saluran irigasi. Kemampuan menghubungkan unsur-unsur alam serta memanfaatkannya adalah kemampuan berpikir masyarakat setempat yang sudah ada sejak lama. Kemampuan berpikir aplikasi dan interaksi spasial tersebut dibuktikan dengan lahan sawah seluas 5.915,4 ha (BPS, 2016).

Begitu pula dengan simbol hamparan hijau yang bermakna bahwa masyarakat mempunyai kemampuan berpikir representasi. Kemampuan representasi merupakan kemampuan berpikir spasial yang dapat mewakili kondisi nyata dengan hal-hal yang berbentuk abstrak. Kemampuan yang secara denotasi mengandung makna bahwa daerah ini terdapat daerah yang subur dan dimanfaatkan untuk pertanian dan perkebunan. Secara konotasi, makna hamparan hijau bermakna masyarakat terbuka akan hal-hal baru dan positif yang berasal dari luar.

Kemampuan berpikir analisis, komprehensif dan representasi juga terlihat dari simbol motto Tau Jo Nan Ampek. Kemampuan analisis dan representasi tergambar dari kemampuan masyarakat menganalisis tujuan hidup yang simbolnya diwakili oleh empat arah mata angin. Bentuk simbol Tau Jo Nan Ampek (Asa diri nan ampek dan Mato angin nan ampek) dapat berarti bahwa terdapat kemampuan berpikir untuk menentukan arah/tujuan hidup berdasarkan analisis berbagai kemungkinan yang akan terjadi. Kemampuan dalam menganalisis juga disertai dengan kemampuan menghubungkan kemungkinankemungkinan tersebut (komprehensif).

\section{KESIMPULAN}

Masyarakat Minangkabau telah lama mengenal kearifan lokal. Kearifan lokal merupakan gambaran kemampuan berpikir masyarakat dalam mengetahui, memahami dan beradaptasi terhadap alam dan kehidupannya. Berpikir spasial pada masyarakat Minangkabau merupakan berpikir kognitif karena masyarakat mampu melakukan transisi dan menggabungkan informasi dari unsurunsur fisik/alam yang kemudian direpresentasi dalam bentuk simbol. Kemampuan berpikir spasial masyarakat Minangkabau tercermin dari simbol-simbol yang terdapat pada logo pemerintahan daerah. Makna simbol unsur fisik pada logo daerah mengandung makna denotasi dan konotasi. Makna yang terkandung dalam simbol tersebut perlu diketahui masyarakat Sumatera Barat untuk melestarikan kearifan lokal masyarakat Minangkabau yang sejak dahulu terkenal dengan kemampuan berpikirnya.

\section{DAFTAR PUSTAKA}

Alam, Q., \& Kusumasari, B. (2012). Local wisdom-based disaster recovery model in Indonesia. Disaster Prevention and Management: An International Journal, 21(3), 351-369. https://doi.org/10.1108/09653561211 234525

Aliman, M. (2018). Menguak Tradisi Lokal (1st ed.). Surabaya: CV.Cipta Media Edukasi.

Aliman, M., \& Arif, M. (2017). Pengintegrasian Nilai Kearifan Lokal Minangkabau dalam Konservasi Sungai melalui Pembelajaran Geografi. Prosiding Peningkatan Literasi Informasi Geografi dan Kebencanaan untuk Pembangunan Pesisir dan daerah Aliran Sungai, 1, 479. Yogyakarta: BPFG.

Aliman, M., Budijanto, Sumarmi, Astina, I. K., Putri, R. E., \& Arif, M. (2019). The Effect of Earthcomm Learning Model and Spatial Thinking Ability on Geography Learning Outcomes. Journal of Baltic Science Education, 18(3), 323-334.

https://doi.org/10.33225/jbse/19.18. 323

Aliman, M., Mutia, T., \& Yustesia, A. (2018). Integritas Kebangsaan dalam Tes Berpikir Spasial. Prosiding Seminar 
Nasional Pendidikan Geografi FKIP UMP 2018, 82-89. Purwokerto: UM Purwokerto Press.

Barthes, R. (1972). Mythologies. New York.

Berger, A. A. (2015). Pengantar Semiotika, Terjemahan: Sign in Contemporary Culture: An Introduction to Semiotics (4th ed., Vol. 1). Yogyakarta: Tiara Wacana.

BMKG. (2018). Prakiraan Cuaca Pulau Punjung (Kab. Dharmasraya) Sumatera Barat | BMKG. Retrieved November 13, 2018, from https://www.bmkg.go.id/cuaca/pra kiraan-

cuaca.bmkg?Kota=Pulau \%20Punjung $\&$ AreaID $=501552 \&$ Prov $=32$

BPS. (2016). Badan Pusat Statistik Kabupaten Dharmasraya. Retrieved November 13, 2018, from https://dharmasrayakab.bps.go.id/d ynamictable/2017/05/19/80/luaslahan-sawah-menurut-kecamatandan-jenis-pengairan-di-kabupatendharmasraya-hektar-2015-.html

Climate-Data. (2018a). Iklim: Grafik iklim Padang Panjang, grafis Suhu, tabel Iklim - Climate-Data.org. Retrieved November 11, 2018, from https://id.climate-

data.org/asia/indonesia/westsumatra/padang-panjang-47908/

Climate-Data. (2018b). Iklim: Grafik iklim Pariaman, grafis Suhu, tabel Iklim Climate-Data.org. Retrieved November 11, 2018, from https://id.climatedata.org/location/618646/

Delita, F. (2016). Studi Perubahan Tutupan Lahan untuk Permukiman Sebelum dan Sesudah Gempa Padang 2009 di Kecamatan Koto Tangah Kota Padang Provinsi Sumatera Barat. JURNAL GEOGRAFI, $8(1)$. https:// doi.org/10.24114/jg.v8i1.5321

Gani, E. (2012). Kajian Terhadap Landasan Filosofi Pantun Minangkabau. Komposisi: Jurnal Pendidikan Bahasa, Sastra, Dan Seni, 10(1). https:// doi.org/10.24036/komposisi. v10i1.49
Gusman, D. (2011). Simbol Religius pada Rumah Gadang Abai Sangir, Solok Selatan. WACANA ETNIK, 2(1), 1-10.

Huynh, N. T., \& Sharpe, B. (2013). An Assessment Instrument to Measure Geospatial Thinking Expertise. Journal of Geography, 112(1), 3-17. https://doi.org/10.1080/00221341.20 12.682227

Littlejhon, S. W., \& Foss, K. (2009). Teori Komunikasi, Theoris of Human Communication (9th ed.). Jakarta: Salemba Humanika.

Meliono, I. (2016). Understanding the Nusantara Thought and Local Wisdom as an Aspect of the Indonesian Education. TAWARIKH, 2(2). Retrieved from http:/ / www.mindamasjournals.com/index.php/tawarikh/ar ticle/view/392

Mubah, A. S. (2011). Strategi Meningkatkan Daya Tahan Budaya Lokal dalam Menghadapi Arus Globalisasi. Jurnal Unair, 24(4), 302-308.

Navis, A. A. (1984). Alam Terkembang Jadi Guru: Adat dan Kebudayaan Minangkabau. Jakarta: Grafiti Press.

Rustiyanti, S. (2014). Musik Internal dan Eksternal dalam Kesenian Randai. Resital: Jurnal Seni Pertunjukan, 15(2), 152-162.

https://doi.org/10.24821/resital.v15i 2.849

Simatupang, O. (2017). Analisis Semiotik Mitigasi Bencana Tsunami dalam Film "Pesan dari Samudera." Jurnal PIKOM (Penelitian Komunikasi Dan Pembangunan), 18(2), 105-124. http://dx.doi.org/10.31346/jpkp.v18i 2.1158

Sufia, R., Sumarmi, S., \& Amirudin, A. (2016). Kearifan Lokal dalam Melestarikan Lingkungan Hidup (Studi Kasus Masyarakat Adat Desa Kemiren Kecamatan Glagah Kabupaten Banyuwangi). Jurnal Pendidikan: Teori, Penelitian, dan Pengembangan, 1(4), 726-731.

Sugiharto, S., Delita, F., \& Sidauruk, T. (2018). Tingkat Kesiapan Masyarakat 
Lokal Terhadap Pengembangan Community Based Tourism (CBT) di Kabupaten Samosir. JURNAL GEOGRAFI, 10(2), 157-163. https:// doi.org/10.24114/jg.v10i2.104 19

Suharjanto, G. (2011). Membandingkan Istilah Arsitektur Tradisional Versus Arsitektur Vernakular: Studi Kasus Bangunan Minangkabau dan Bangunan Bali. ComTech: Computer, Mathematics and Engineering Applications, 2(2), 592-602. https:// doi.org/10.21512/comtech.v2 i2.2808

Sumarmi. (2015). Local Wisdom of Osing People in Conserving Water Resources. Komunitas: International Journal of Indonesia Society and Culture, 7(1),

43. https:// doi.org/10.15294/komunitas. v7i1.3429

Sumarmi. (2016). A Study of Local Wisdom of Balinese Aga And Samin People to Develop Environmental Awareness Characteristics. Advances in Social Science, Education and Humanities Research, 79, 201-205. Retrieved from (http://creativecommons.org/license s/by-nc/4.0/).

Syamsidik, Istiyanto, D. C., Tanto, T. A., \& Rachman, R. A. (2011). Peran Tata Ruang Tingkat Desa dalam Upaya Mitigasi Bencana Tsunami di
Kepulauan Mentawai, Indonesia. Prosiding Seminar Nasional Hasil Penelitian Kebencanaan, 78-83.

Wirda, M. A. (2016). Analisis Bahaya Longsor di Kecamatan Bayang Utara Kabupaten Pesisir Selatan Sumatera Barat. JURNAL GEOGRAFI, 8(1). https://doi.org/10.24114/jg.v8i1.5319

Ws, H. (2015). Kearifan Lokal dalam Tradisi Lisan Kepercayaan Rakyat Ungkapan Larangan Tentang Kehamilan, Masa Bayi, dan Kanak-kanak Masyarakat Minangkabau Wilayah Adat Luhak Nan Tigo. KEMBARA: Jurnal Keilmuan Bahasa, Sastra, Dan Pengajarannya, 1(2), 198-204.

https://doi.org/10.22219/kembara.v1 i2.2615

Yulika, F. (2017). EPISTEMOLOGI MINANGKABAU: Makna Pengetahuan dalam Filsafat Adat Minangkabau. ISI Padangpanjang.

Yuningsih, R. (2015). Peningkatan Kecerdasan Kinestetik Melalui Pembelajaran Gerak Dasar Tari Minang. Jurnal Pendidikan Usia Dini, 9(2), 233-250. https://doi.org/10.21009/JPUD.092.0 3 